\title{
Gamification for Elementary Mathematics Learning in Indonesia
}

\author{
Yogi Udjaja ${ }^{1}$, Vincent Sadino Guizot ${ }^{2}$, Natalia Chandra ${ }^{3}$ \\ ${ }^{1,3}$ Computer Science Department, School of Computer Science, Bina Nusantara University, Jakarta, Indonesia 11480 \\ 1,2Ekspanpixel, Jakarta, Indonesia 11480
}

\begin{tabular}{l} 
Article Info \\
\hline Article history: \\
Received Jun 30, 2018 \\
Revised Sep 20, 2018 \\
Accepted Sep 28, 2018 \\
\hline
\end{tabular}

Keyword:

Elementary mathematics learning education

Expert system

Gamification

GDLC

Indonesia

Learning instrument

Corresponding Author:

Yogi Udjaja,

Computer Science Department,

School of Computer Science,

Bina Nusantara University,

Jl. K.H. Syahdan No. 9, Kemanggisan, Palmerah, Jakarta Barat, Indonesia 11480.

Email: yogi.udjaja@binus.ac.id

\begin{abstract}
The purpose of this research is to combine multimedia elements and mathematics learning material to a mathematic learning interactive application. Research and design methodology that used is Game Development Life Cycle (GDLC) which consist of initiation, pre-production, production, testing and release. Content inside the game is made using gamification and expert system concept. The result of this research is an interactive learning game to support student to understand mathematic materials. The purpose of this application is to help student to learn mathematic in an interactive and interesting way, to deliver mathematic material easily.
\end{abstract}

Copyright $@ 2018$ Institute of Advanced Engineering and Science. All rights reserved.

\section{INTRODUCTION}

Indonesia is one of the biggest country with population about 250 million people [1] Many Indonesia people interested on continuing their study but could not because of economic problem, because of it, many people choose to work instead of education. Whereas, in Constitution of the State of Republic of Indonesia 1945 Article 31 chapter 1 stated that "Every citizen shall have the right of education", and on chapter 3 asserted that "The government seeks and organizes a national education system that enhance faith and piety and noble character to educate the life of the nation which is regulated by law" [2]. It is discussed in the Elucidation of Law of the Republic of Indonesia number 20 year 2003 on National Education System that stated, "All component of the nation must educate the life of the nation which is one of the goals of the state of Indonesia" [3].

In article 1 paragraph 1 of Law of the Republic of Indonesia number 20 year 2003 on National Education System stated that "Education is a conscious and planned effort to create an atmosphere of learning and learning process so that learners actively develop their potential to have spiritual power, selfcontrol, personality, intelligence, noble character, and skills that needed for himself, society, nation and state". Inferences obtained is that the education can increase the potential within someone, which indirectly can improve the economy of the community [4]. To help this, the United Nation (UN) also raised the educational factor into its program established in Sustainable Development Goals (SDGs) [5].

To increase the interest and quality of education is not only government responsibility but also the responsibility of everyone in Indonesia. Therefore, this research is focused in learning mathematics. According to reference [6], someone mathematics ability id directly proportional to someone creativity and 
affects the state's economy. Form the mathematical achievement, it can gained predict "academic success, future employment, economic productivity [7] and health [8]".

Nowadays, Mathematic is one of the compulsory subjects that taught at elementary school, junior high school, and senior high school. In general, student think that mathematic is one of the hardest subject, because student must memorize formula, follow the examples of the completion of the given problem, and delivery lesson material that is considered less interesting.

In studying mathematics, student think must have a strong memory to memorize all the existing formulas. However, what is needed is an understanding of a mathematical problem using right formula. Right now, almost every mathematic textbook includes problem and solutions examples. It aims to enable learners to fully understand the material they are learning. However, the learner tends to follow the solution of the given problem, so when the given problem slightly different from given example, the learner has difficulty solving it.

According to the survey, the most common method of teaching in schools is listening to teacher explanations. When students do not understand the given explanation, they will ask the teacher to give further explanation. Although this method is used by almost teacher while teaching, this method does not guarantee all the students can follow the lesson well. In addition, there is a tendency for students to feel saturated quickly. These are called dyscalculia, where dyscalculia is a person's inability to learn mathematics [6]. According to reference [9], dyscalculia experienced by each person is different, and its effect on each stage of human development also different. This happens because of visual-spatial and language-processing difficulties. Visual-spatial difficulties are a person's problem in processing what is seen. Languageprocessing difficulties are a person's problem in processing and understanding what is being heard.

According to refrence [10] there are factors in which one's learning style is also related to psychological, which depends on the readiness of a person to think, feel, hear and practice. When someone has considered something unattractive then learning will be easily forgotten, because it is not repeated (trained). Therefore, it takes an application or teaching application that can deliver the material by attracting and facilitating the learner to understand it.

\section{RESEARCH METHOD}

In this research, method that used is game development life cycle (GDLC), where there is initiation, pre-production, production, testing and release [11]. Figure 1 shows the game contents are made using gamification method and expert system.

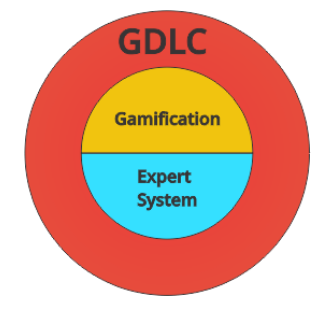

Figure 1. Game development life cycle content system

According to refrence [11]-[15], gamification is a creative way of learning that has a tremendous power of influence to improve the level of learning independence and improve someone mathematic skills, subsequently expert system is needed to create content from mathematical learning. At the time of the test, this study was conducted using pre-test and post-test, where the result obtained viewed based on experimental results at the beginning and at the end after the user tried the created game. This is made to prove whether the game created can improve someone mathematic skill or not. In making a game, it requires a strong attraction, because it deals with human psychology. Everyone who plays games must have a different feeling about a game, but how do we get someone to survive in game play requires a good user interface (UI), user experience (UX) and game play experience $(\mathrm{GX})$. Therefore, a survey is also made to obtain the results of the evaluation.

\section{SIMILAR APPLICATION COMPARISON ANALYSIS}

There are several applications that been developed before, as a part of the game development life cycle, analysis to similar application been done. There are 3 application that been analysis which are Magic Math, Mahir matematika kelas 6 SD, kumpulan soal interaktif kelas 6A. 
Table 1. Similar Application Comparisons

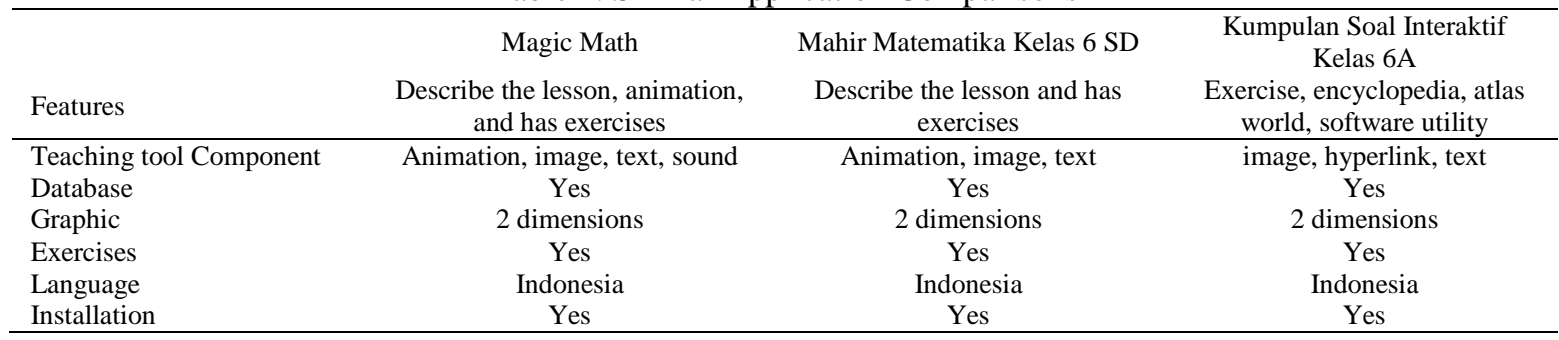

\section{RESULTS AND ANALYSIS}

The use case of the application can be viewed in Figure 2. It shows how the user interact with the system and show several features that implemented in the application.

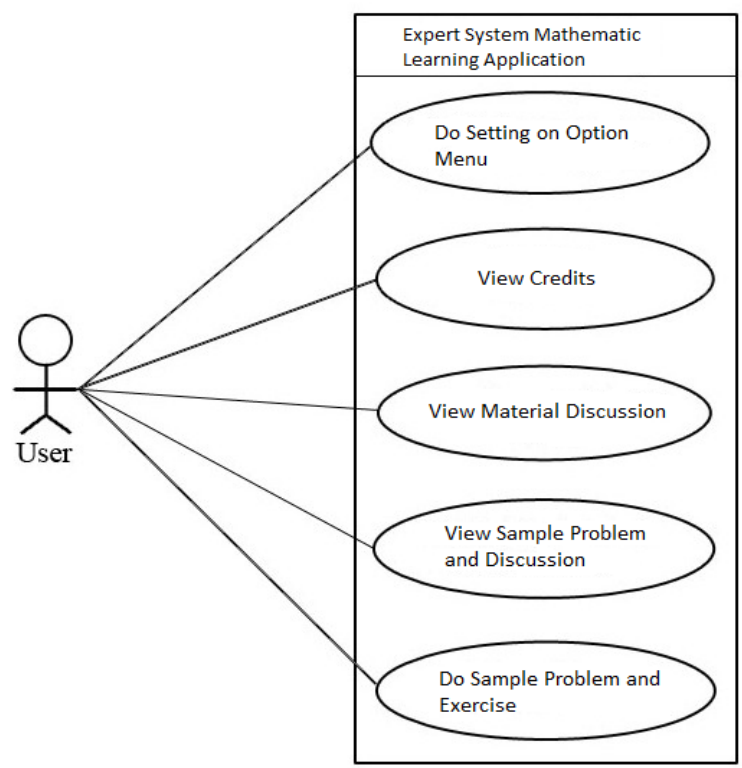

Figure 2. Mathematic learning application use case

The strategy is to invite the users to learn Mathematics by utilizing multimedia elements, such as images, sound, text, and animation. Submission of material is given in the form of animation so that the material can be more easily understood as shown in Figure 3. In the 'Sample Problems and Discussions' section, this application provides examples of commonly-given questions, and the discussion of the questions is also presented in animation, which helps the user to gradually understand the problem first, followed by the solution as shown in Figure 3.

Users can also work on the exercises in the 'Problems and Exercises' section. It aims to test the user's understanding of the newly delivered material. When the user has completed the exercise questions, the application will display the value and the number of true and false questions as shown in Figure 7. When the user has completed the exercise questions, the application will display the value and the number of true and false questions as shown in Figure 3.

This game is tested to 30 teachers to test the standard whether it is in accordance with the existing curriculum. Then tested to 100 students in Indonesia, which result 87 people experience improvement in working on mathematical problems that have been provided, 9 people the results of the post-test is equal to the pre-test, and 4 people suffered setbacks. When considered again, these things because of the attraction Pull someone to learn, where the asset game in the form of images and animations in the game should be improved. Due to some input from teachers and students, and judging by direct observation, one's interest to learn lies in the created images and animations as well as the interaction in the game in the form of gameplay experience. 

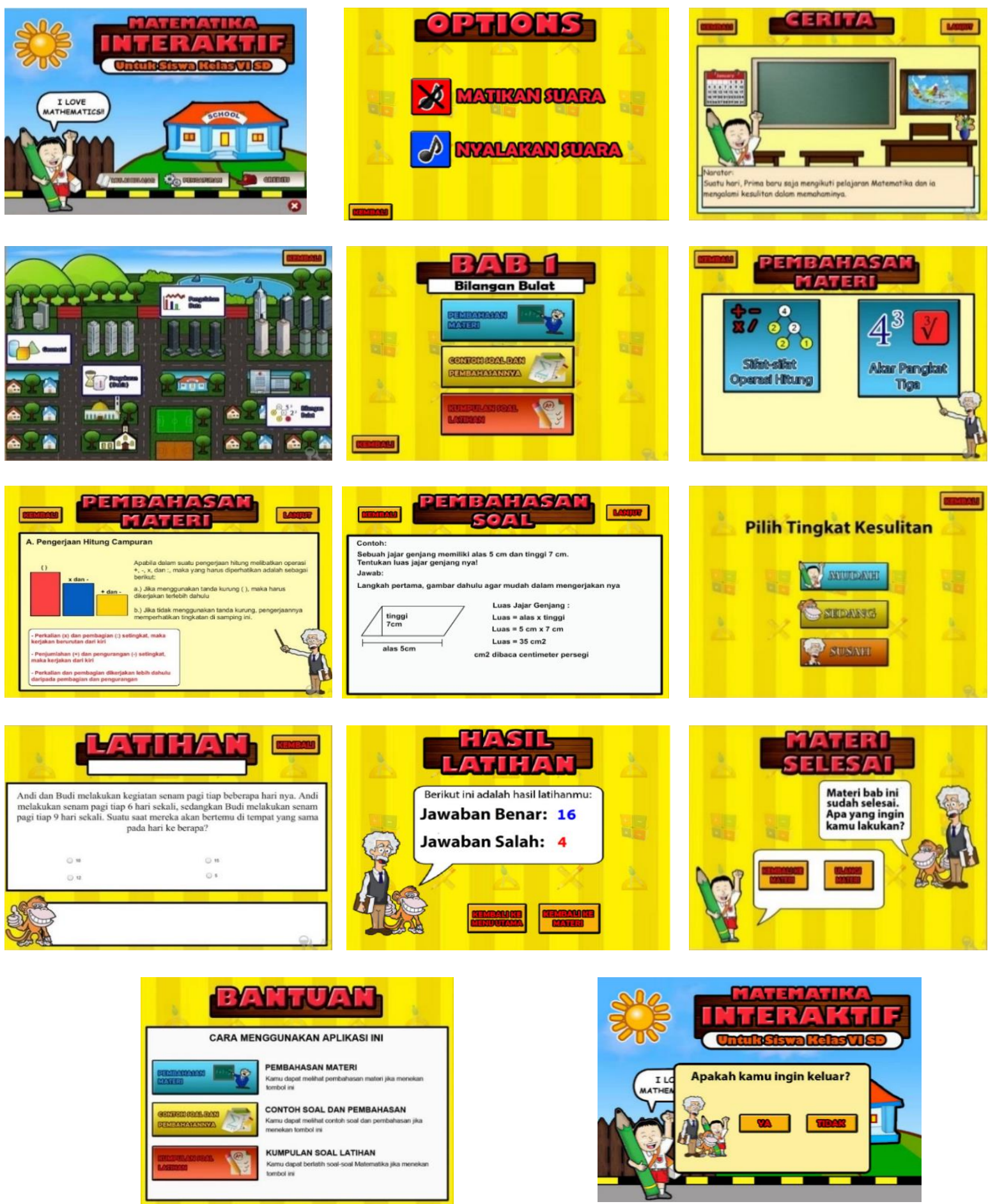

Figure 3. Interactive mathematic application

\section{EVALUATION}

Here is the result of the evaluation of the user interface, user experience and gameplay experience of game that been developed:

a. What do you think about teaching application regarding the User interface, sound, and features?

Table 2. Students and Teachers Opinion about Interactive Mathematic Application

\begin{tabular}{lcccc}
\hline Answers & Total Teacher & Total Student & Total & Percentage \\
\hline Very interesting & 3 & 12 & 15 & $11.5 \%$ \\
Interesting & 20 & 67 & 87 & $66.9 \%$ \\
\hline
\end{tabular}


Table 2. Students and Teachers Opinion about Interactive Mathematic Application

\begin{tabular}{lcccc}
\hline Answers & Total Teacher & Total Student & Total & Percentage \\
\hline Quite interesting & 7 & 21 & 28 & $21.5 \%$ \\
Not interesting & 0 & 0 & 0 & $0.0 \%$ \\
Very uninteresting & 0 & 0 & 0 & $0.0 \%$ \\
Total & 30 & 100 & 130 & $100 \%$ \\
\hline
\end{tabular}

b. Are the materials described in the learning discussion feature easy to understand?

Table 3. Students and Teachers Opinion about Learning Material Explanation

\begin{tabular}{lcccc}
\hline Answers & Total Teacher & Total Student & Total & Percentage \\
\hline Very Clear & 25 & 48 & 73 & $56.2 \%$ \\
Clear & 5 & 38 & 43 & $33.1 \%$ \\
Quite clear & 0 & 14 & 14 & $10.8 \%$ \\
Unclear & 0 & 0 & 0 & $0.0 \%$ \\
Not clear & 0 & 0 & 0 & $0.0 \%$ \\
Total & 30 & 100 & 130 & $100 \%$ \\
\hline
\end{tabular}

c. What do you think about the exercise given in the problem solved feature?

Table 4. Students and Teacher Opinion Concerning Level Problem Exercise difficulty

\begin{tabular}{lcccc}
\hline Answers & Total Teacher & Total Student & Total & Percentage \\
\hline Very easy & 6 & 14 & 20 & $14.0 \%$ \\
Easy & 21 & 43 & 64 & $43.0 \%$ \\
Quite easy & 3 & 41 & 44 & $41.0 \%$ \\
Difficult & 0 & 2 & 2 & $2.0 \%$ \\
Very Difficult & 0 & 0 & 0 & $0.0 \%$ \\
Total & 30 & 100 & 130 & $100 \%$ \\
\hline
\end{tabular}

d. Is the interactive Mathematic application makes student more interested in learning mathematics?

Table 5. Teachers and Student Level of Interest using the Learning Application

\begin{tabular}{lcccc}
\hline Answers & Total Teacher & Total Student & Total & Percentage \\
\hline Very Interest & 0 & 12 & 12 & $9.2 \%$ \\
Interest & 19 & 69 & 88 & $67.7 \%$ \\
Neutral & 11 & 19 & 30 & $23.1 \%$ \\
Less interest & 0 & 0 & 0 & $0.0 \%$ \\
Not interested & 0 & 0 & 0 & $0.0 \%$ \\
Total & 30 & 100 & 130 & $100 \%$ \\
\hline
\end{tabular}

e. How much does this learning application help you to learn mathematic?

Table 6. Students and Teacher Opinion about Learning Application helps in Mathematic Learning

\begin{tabular}{lcccc}
\hline Answers & Total Teacher & Total Student & Total & Percentage \\
\hline Very helpful & 0 & 13 & 13 & $10.0 \%$ \\
Helpful & 30 & 68 & 98 & $75.4 \%$ \\
Quite helpful & 0 & 19 & 19 & $14.6 \%$ \\
Not helpful & 0 & 0 & 0 & $0.0 \%$ \\
Very not helping & 0 & 0 & 0 & $0.0 \%$ \\
Total & 30 & 100 & 130 & $100 \%$ \\
\hline
\end{tabular}

\section{CONCLUSION}

This game is developed to help student to learn mathematic in interactive way and help teacher to explain mathematic material. Multimedia elements such as text, images, sound, animation serve as an interactive way for student to learn mathematic and increase student interest in learning. Based on the results obtained this game application needs to improve in the image quality and has more animation developed inside game that contains material explanations in order the learner can understand more deeply. Beside that, currently the mathematic material only covers for elementary level, in the future the material will be added variative until high school level. 


\section{REFERENCES}

[1] Jamrah, A., "Shaping Golden Generation through Character Education toward 100 Years Indonesia", Proceeding IAIN Batusangkar, vol. 1, no. 2, pp. 41-50, 2017.

[2] Undang-Undang Dasar Negara Republik Indonesia Tahun 1945 Pasal 31 ayat 1 dan 3.

[3] Penjelasan Undang-Undang Republik Indonesia Nomor 20 Tahun 2003 Tentang Sistem Pendidikan Nasional. Diakses tanggal 09 November 2017 pk. 16.32, pada:

http://keuda.kemendagri.go.id/produkhukum/download/477/penjelasan-uu-no-20-tahun-2003

[4] Undang-Undang Republik Indonesia Nomor 20 Tahun 2003 Tentang Sistem Pendidikan Nasional. Diakses tanggal 09 November $2017 \quad$ pk. 15.12, pada: http://kelembagaan.ristekdikti.go.id/wpcontent/uploads/2016/08/UU_no_20_th_2003.pdf

[5] Yunanto, A., et al., "Pengembangan Ekonomi Sosial Dalam Sektor Pertanian Dengan Menggunakan Hydroponic Tower System”, Procedings National Confrence on Corporate Social Responsibility, vol. 1, pp. 34-43, 2016.

[6] Simms, V., et al., "Interventions to Improve Mathematics Achievement in Primary School-aged Children: A Systematic Review", 2017.

[7] Williams, J., et al., "The Skills for Life survey: A national needs and impact survey of literacy, numeracy and ICT skills", United Kingdom: Department for Education and Skills, 2013. https://www.gov.uk/government/uploads/system/uploads/attachment_data/file/36000/12-p168-2011-skills-for-lifesurvey.pdf

[8] Rowlands, G., "Health Literacy: Ways to Maximise the Impact and Effectiveness of Vaccination Information", Human Vaccines \& Immunotherapeutics, vol. 10, no. 7, pp. 2130-2135, 2014.

[9] De Visscher, A., et al., "Developmental Dyscalculia in Adults: Beyond Numerical Magnitude Impairment", Journal of Learning Disabilities, 0022219417732338, 2017.

[10] Su, C., "Designing and Developing a Novel Hybrid Adaptive Learning Path Recommendation System (ALPRS) for Gamification Mathematics Geometry Course", Eurasia Journal of Mathematics, Science undn\& Technology Education, vol. 13, no. 6, pp. 2275-2298, 2017.

[11] Yan Fi, et al., "A Gamification Interactive Typing for Primary School Visually Impaired Children in Indonesia", Procedia Computer Science, vol. 116, pp. 638-644, 2017.

[12] Baldeon, J., et al., "Gamification of Elementary Math Learning: A Game Designer Role-Playing Experience with Kids", gEducation (GWC15), 2015.

[13] Kuswardhana, D., et al., "The Instructional Thematic Game for Children with Mild Mental Retardation: For Enhancement of Left-Right Recognition Skill”, International Journal of Electrical and Computer Engineering, vol. 7, no. 1, p. 469, 2017.

[14] Setiana, H., \& Hansun, S., "Gamified Android Based Academic Information System”, International Journal of Evaluation and Research in Education (IJERE), vol. 6, no. 2, pp. 164-173, 2017.

[15] Okpube, N. M., \& Anugwo, M. N., "Card Games and Algebra Tic Tacmatics on Achievement of Junior Secondary II Students in Algebraic Expressions", International Journal of Evaluation and Research in Education, vol. 5, no. 2, pp. 93-100, 2016.

\section{BIOGRAPHIES OF AUTHORS}

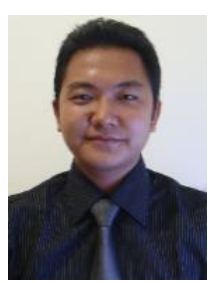

Yogi Udjaja was born in Padang, 15 October 1993. He received Bachelor of Computer Science and Master of Information Technology degree from Bina Nusantara University in 2014 and 2016, respectively. His research interests are Multimedia, Game Technology, Holography and Computational Intelligence. He is a Founder and CEO of Ekspanpixel Company and lecturer at School of Computer Science, Bina Nusantara University.

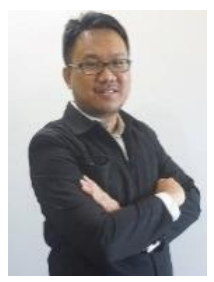

Vincent Sadino Guizot was born in Cirebon, 12th of August 1992 and schooled in one of the best private School in cirebon, after he graduated, he continued to college in Binus University, and took Information Technology, Multimedia System as his study. Now he is an It Instructor in Course Net. He teaches Calculus I and II. Math Discrete, and Algorithm.

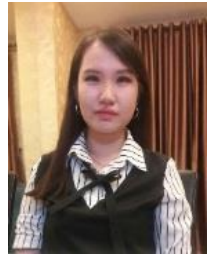

Natalia Chandra was born in Medan City, Jakarta, in 1988. She received her B.S degree in System Information from the Bina Nusantara University in 2010 and M.Sc degree from King Mongkut University of North Bangkok, Thailand in 2012. From 2013 to the present, she is a lecture at department of School of Computer Science, Bina Nusantara University. Her research interest includes mobile application and software engineering. 